\title{
“LEFT-RIGHT" PARTY-IDEOLOGICAL DELINEATION AS A PRINCIPAL MEAN OF STRUCTURING OF THE POLITICAL LANDSCAPE
}

\section{Shypunov H. V., Prokop M.}

\section{INTRODUCTION}

Having emerged (mostly accidentally) in the late XVIII century in France, the concept of "left-right" party-ideological delineation nowadays has become one of the most widespread and universal methods for structuring of the political landscape, which is actively used both in the political science research and in the journalistic discourse. Paying homage to the important role that this concept plays in the modern political science, we may also derive two principal functions, which this concept plays in the real social and political life: on the collective life, it is beneficial for social orientation and simplifies political communication. Thus, it functions as a symbolic system of coordinates, which enables parties to perform their positioning and stand out among another political forces, having tied own political position with the place in the said system. On the individual level, this concept helps people to make a reasoned political choice based thereon ${ }^{1}$.

Introduction and definitive establishment of the "left-right" semantics in the political science discourse, which, however, is characterised by the instability of the principal terms (they are constantly changing, attracting new features and content depending on one or another social and political context, or even political traditions, which are ruling in a certain region ${ }^{2}$ ), gave push to a continued scientific discussion regarding the specifics of conceptualisation of the mentioned delineation and its research potential ${ }^{3}$. We should also stress here that Western political science is represented by a whole complex

${ }^{1}$ Knutsen O. Value Orientations, Political Conflicts and Left-Right Identification: A Comparative Study. European Journal of Political Research. 1995. Vol. 28, Issue 1. P. 63.

2 Jahn D. What is Left and Right in Comparative Politics? A Response to Simon Franzmann. Party Politics. 2014. Vol. 20, Issue 2. P. 297-298.

${ }^{3}$ Huber J., Inglehart R. Expert Interpretations of Party Space and Party Locations in 42 Societies. Party Politics. 1995. Vol. 1, Issue 1. P. 74. 
of the fundamental research of the specifics of "left-right" delineation. This is evidenced by the works of, among others, N. Bobbio, D. Jahn, J. Huber, R. Inglehart, H. Klingemann, H. Kitschelt, M. McDonald, C. de Vries. At the same time, we can make a conclusion that this issue is underresearched within the framework of Ukrainian political science. Certain separate aspects of this issues are analysed in the works of Y. Shveda, A. Romanyuk, A. Kolodiy, M. Karmazina, A. Glivinskyi, M. Prymush.

The topicality of this problem and its underdevelopment within the framework of our native political science formulates principal goals of our research: firstly, a methodological clarification of the substantial characteristic of the notions "left", "right" and "center"; secondly, determination of the criteria of delineation based thereon, which, in its turn, would allow us to clearly identify left, right and centrist parties; thirdly, definition and research of the specifics of the "left-right" partyideological delineation, which have developed in the political landscape of the post-communist states in the Central and Eastern Europe in the context of their double transit - to the democracy and market economy.

\section{Left and Right: Principal Approaches to the Conceptualisation in the Political Science}

As of today, there are two principal approaches in the political science to the definition of values and issues that form the content consistency of the left and right dimensions of the political landscape: deductive (a priori) and inductive (a posteriori).

The notion of the first one lies in the deriving of the content characteristics of the left and right in the political theory, namely, from the classical works of the philosophical and political thinking and defining researches of the representatives of political science. The adherents of the second approach formulate the criteria for left and right based on the empirical observations: they perform preliminary measurements of the party and social positions out of the several issues in the society used as indicators for creating specific constructions, which the researcher later interprets. Therefore, the substantial definitions of the left and right in this aspect are the result of their analytical interpretation. In other words, the basis of this approach is the empirical definition of 
those problematic issues, which are common for certain parties. This allows to unite them in a joint left or right party family ${ }^{4}$.

Defining the indicators for the left, right and centrist parties, we would be using the positions of the deductive approach. Let us refer to the theory and classics of the political science. In 1957 A. Downs was one of the first to apply space analogy of the "left-right" positioning of the parties and ideologies (in the form of a linear scale). In his words, the principal question, which allows to make such a delineation is a measure of state involvement into the economy: left ending of the scale represents a total state control, while right stands for a completely free market ${ }^{5}$.

Other representatives of the American political science S. Lipset, P. Lazarsfeld, A. Barton and J. Linz, while researching the electoral behaviour of voters, were considering the following criteria of the delineation: the left ones are those, who stand for social changes in the direction of the larger equality - political, economic and social; right ones are those, who support traditional, more or less hierarchical order, as well as resent those changes leading to a larger equality ${ }^{6}$.

Transition of the leading industrial states to a post-industrial stage of development, which was remarkable, namely, due to the change of value priorities of those societies (the forefront was taken by the new, postmaterial problems connected with the quality of life and personal selfidentification $^{7}$ ), placed a question of the adequacy of the "left-right" dichotomy within the new social and political conditions. In this context, R. Inglehart and H. Klingemann, emphasizing, on one hand, that the crucial problems, which in complex determine the "left-right" dimension, and on the other hand, "identified a constant and omnidirectional issue", which allows to identify left and right. They were of the opinion that despite of the significance of the economic equality has somewhat lowered, the lefts have remained typical defenders of the changes, which were aimed at achievement of a larger equality, specifically emphasizing on the equal involvement of everyone in a political and social life.

${ }^{4}$ Jahn D. What is Left and Right in Comparative Politics? A Response to Simon Franzmann. Party Politics. 2014. Vol. 20, Issue 2. P. 297-298.

${ }^{5}$ Downs A. An Economic Theory of Political Action in a Democracy. The Journal of Political Economy. 1957. Vol. 65, Issue 2. P. 141-142.

${ }^{6}$ Weber W. Behind Left and Right. The Meaning of Left-Right Orientation in Europe URL: http://www.tdx.cat/bitstream/handle/10803/107624/tww.pdf? sequence=1. P 97. (дата звернення: 21.05.2018).

${ }^{7}$ Инглхарт Р. Постмодерн: меняющиеся ценности и изменяющиеся общества. Полис. 1997. № 4. С. 6-32. 
Whereas the defining feature of the right is a hierarchical order. Therefore, the essential dilemma of the politics is an opposition between the equality and traditional (hierarchical) order ${ }^{8}$.

It is a question of equality, quoting the Italian thinker N. Bobbio, that is a constant end value defining the "left-right" delineation". By naming the lefts as egalitarian and the rights as anti-egalitarian, he emphasizes that while the first ones do not deny the fact that people are as equal as they are unequal, they also prefer that what makes them equal, rather than unequal. In their turn, the latter, deriving from the same situation, within the same conditions prefer that what makes people unequal rather than equal. The contrast between the end choices, in the opinion of N. Bobbio, is the best to mark the lefts and the rights.

In practice, this delineation transforms into the difference in evaluation of what is relevant for justification or denial of the discrimination. Therefore, we mean the definition of a criterion (or criteria) of discrimination. This depends on the approach to the level of importance of certain forms of differences, which ones (anti-egalitarian) consider a sufficient ground for unequal treatment, and others (egalitarian) don't: egalitarian are striving to level the differences (meaning to lower the amount of grounds for discrimination), whereas the anti-egalitarians are inclined to overestimate their importance (which means to increase the grounds for discrimination $)^{10}$.

The conceptual approach of $\mathrm{N}$. Bobbio has gained a widespread popularity in the modern political science. Aside from the existence of certain sceptic views on his empirical adequacy in the context of determination of substantial differences between left and right, such approach become a foundation of the many further research attempts of this opposition ${ }^{11}$. Namely, German researcher D. Jahn based on this approach developed an original concept of the "left-right" delineation.

${ }^{8}$ Inglehart R., Klingemann H.-D. Party Identification, Ideological Preference and the Left-Right Dimension among Western Mass Publics. Party Identification and Beyond: Representations of Voting and Party Competition / I. Budge, I. Crewe, D. J. Farlie (eds.). Colchester: ECPR Press, 2010. P. 258-259.

${ }^{9}$ Bobbio N. Left and Right: The Significance of a Political Distinction / translated and introduced by A. Cameron. Chicago: The University of Chicago Press, 1997. P. 58-59.

${ }^{10}$ Ibid. P. 66-70.

${ }^{11}$ Rosas J. C., Ferreira A. R. Left and Right: Critical Junctures. Left and Right: The Great Dichotomy Revisited / J. C. Rosas, A. R. Ferreira (eds.). Newcastle upon Tyne: Cambridge Scholars Publishing, 2013. P. 6-9. 
In our view, we should first of all pay attention to the following methodological principles of such approach. Firstly, to resolve an internally disputable problem of the stability and changeability of the substantial definitions of the left and right we need to determine pivotal and pivot-related ancillary characteristics of the left and right. This is because such pivotal components are stable and valid in any given time and context, which allows to make clear delineation at all times. Ancillary ones are changing as the time goes by and in specific contexts, which allows to affix the peculiarities of the "left-right" division in different time periods and its national specifics (dependency on a historical and political context of the country or region).

Secondly, while determining the pivotal and ancillary characteristics we need to clearly define the level of their "leftness" and "rightness". In other words, we need to range them from the strongest (those who most definitely influence the belonging to either "left" or "right") to the weakest. Otherwise, a party, which formulates several moderate "left" statements and one mighty "right" declaration, may be classified as left, while having significant grounds to assume the contrary ${ }^{12}$.

Thirdly, the right are not a homogeneous force and are different in their approach to inequality. While agreeing with $\mathrm{N}$. Bobbio that the principal delineation border between the left and right is their different ontological positions in the evaluation of the ideal of equality, D. Jahn simultaneously insists on the necessity of differentiation of the right: one part of the right considers social inequality artificial, while other part - natural.

Such delimitation, on one hand, between the left and right, and on the other hand - between the right themselves finds its description in the three big classic ideologies: socialism, liberalism and conservatism. While the left (socialists) concentrate on the questions of equality, the right (liberals and conservatives) substantiate the objectivity of the existence of inequality differently: conservatism considers it as given by the very nature, while liberalism stems from the fact that the place of the human in the society is determined solely by the human activity ${ }^{13}$.

This approach, which makes a clarification of the characteristics of "left-right" delineation possible, has advantages in both theoretical and

12 Jahn D. Conceptualizing Left and Right in Comparative Politics: Towards a Deductive Approach. Party Politics. 2011. Vol. 17, Issue 6. P. 749-750.

${ }^{13}$ Ibid. P. 751. 
empirical dimensions. This is because it allows to adequately comprehend its variability, in particular, to include to the conceptual description of the left and right new questions of the post-material character. Here we derive from the methodological position of the coexistence of the traditional and new definitions of the left and right, which do not displace one another from the political discourse, but rather become more or less significant in the context of a certain social, political and economic situation $^{14}$. This creates grounds to reassessment of the traditional views on the "left-right" delimitation of the political landscape in the format of a one-dimensional linear division. We are talking about the necessity of considering material and post-material questions in determination of the substantial characteristics of left and right, which transform it into a twodimensional, within which the positioning of the political forces as left and right takes place: under one conditions with the emphasis on the economic matters, under other conditions - on the socio-cultural matters.

Therefore, considering primarily methodological approaches of $\mathrm{N}$. Bobbio and D. Jahn, stemming from the defining meaning of the principle of equality/inequality in the context of delineation of the left and right political parties, we can define the following indicators, which would divide into two clusters.

\section{Left political parties.}

First cluster of indicators - "traditional" (material). The principal thesis of this cluster is the following: the main source of the social, economic and political inequality in the society is the capitalist system, which is founded on free market and private property. Therefore, the strive for overcoming the inequality predetermines the necessity of change of the existing system of relationship and introduction of a new one, which would be based on different grounds.

The substantial characteristics of the new system evolve depending on the level of the "leftness" of claims, which is determined by the ideological positions of political parties. We shall place such characteristics with the respective claims in the descending order of the aforementioned level: 1) communal property over the means of

${ }^{14}$ De Vries C. E., Hakhverdian A., Lancee B. The Dynamics of Voters' Left/Right Identification: The Role of Economic and Cultural Attitudes. Political Science Research and Methods. 2013. Vol. 1, Issue 2. P. 228. 
production (requests of total nationalisation and liquidation of private property); 2) all-around state control and regulation of the social and economic spheres (categorical denial of the principles of free market, requests for establishment of planned principles of organization and management of the economy, adherence to the principle of inclusiveness in the provision of social goods and services); 3) mixed property regime (ability of effective coexistence of private and state property, partial nationalisation); 4) partial state control and market regulation (social market economy, requests of complete realisation of the welfare state, adherence to the principle of wide selectiveness in provision of the social goods and services (to all social groups in need, namely, those, whose material conditions makes it impossible to purchase such goods and services)).

The abovementioned claims, which actually means the change of the capitalist system, may be realised through means of revolution or reform. The revolutionary (radical) way provides for the following: use of violent methods of political struggle and realisation of the doctrinal notions. This means, in particular, the denial of the fundamental democratic principles of political competition, as well as readiness to (necessity of) breaking individual, political and civil rights and freedoms for achieving ideological goals. On the contrary, the reform (considerate way) defines the respect for fundamental civil right and freedoms, recognition and use of the democratic mechanisms as those solely possible instruments of political struggle, which draws a wide field of opportunities for an effective political dialogue with moderate ideological opponents.

Second cluster - "new" (post-material). Key thesis: principles, which define the substantial parameters of functioning of the modern developed industrial society determine social inequality, and, thus, must be dropped and changed to those, which would create a new social reality with the maximum levelling of the inequality.

We should note that here, the principle of equality not only strives to stand out in the economic dimension, but rather to acquire the quality of total emancipation of a human, liberation of human from all traditional form of addictions and limitations, which are brought onto human by the modern market society, obtaining of equal rights in all spheres of the social being. Therefore, we may observe here an increase of the space of necessary emancipation, struggle for which, as of today, got rid of solely economic (material) and social or class character. 
This is evident in the strive for: 1) maximum expansion of the space of individual autonomy and equal rights of human (individual and legal emancipation - defending the right to choose individual lifestyle and struggle for reduction of the criteria for discrimination: gender, sexual, race and national liberation); 2) procurement of the widest and equal participation of citizens in the political process possible (political emancipation - struggle for liberation of the individual from under control of the hierarchical, bureaucratic and oligarchic political and powerful structures of the welfare state; contradistinction of participatory model of democracy to egalitarian model; consequently, denial of the principle of "powerful state" and requests for organisation of state and political life on the foundations of autonomy, solidarity and decentralised networks); 3) levelling of the inacceptable risks of modernisation, which bear threat to human life and the surrounding environment (ecological emancipation - requests for setting up of equal relationship between human and nature, liberation of human from the dangers, which the irresponsible (consumerism) approach to the surrounding environment and militarism pose to him); 4) guaranteeing of the unimpeded access of all citizens to intellectual resources (intellectual emancipation - the requests of lifting all restrictions on the way to obtain the information and knowledge necessary for a person).

We should also pay attention to additional indicators that are directly related to the principal ones: 1) critique of the ideological union between capital and workers, which was concluded in developed industrial societies, resulting in the latter becoming the foundation of the bourgeois lifestyle and become "sublimated slaves of the developed industrial civilisation" "15) 2) critique of the traditional left political parties, which have de facto stopped being left due to: a) compromises with the ideological opponents, joint participation in government and integration into the existent political system; b) retreat from the doctrinal foundations of activity and, as a consequence, loss of historic ideological mission; c) excessive hierarchizing, bureaucratisation and centralisation of the party structures; 3) critique of the establishment for usurpation of the people's sovereignty and de facto monopolisation of the process of approval of political and state decisions.

${ }^{15}$ Маркузе Г. Одномерный человек / пер. с англ. А. Юдина. Москва: REFL-book, 1994. C. $42-43$. 
The issue of attitudes to revolution and violence as methods of political struggle and the realization of ideological settings requires separate clarification. We need to understand here clearly that the idea of revolution in the modern developed society has undergone a deep delegitimising - it is no longer seen as an effective method of performing social, economic and political changes, while at the same time use of violence as a mean of political struggle is seen as a sign of extremism and terrorism. Given this background, the practical reference to those means has become a destiny of the marginalised or semi-legal ultra-left political organisations and social movements.

Therefore, appealing to the idea of revolution in the modern environment is, for many ultra-left representatives, rather a theoretical tribute to the ideological tradition than a direct guidance for practical political action. Under these circumstances, the reassessment of this idea is performed in the spirit of the concept of "molecular aggression into the cultural core" by A. Gramsci ${ }^{16}$. Hence, the revolutionary strategy is considered not within the context of the violent dismantling of the existing system as a result of class opposition, but as a scrupulous fight for change of the opinions and feelings in the consciousness of each individual human being.

Right political parties.

First cluster of indicators - "traditional" (material).

Right (liberals). Main thesis: the free market creates a space of equal opportunities and chances for individuals to realize their abilities and talents. Social inequality is artificial. This means that the place of naturally equal people in their rights and freedoms in the social hierarchy is determined solely by the results of their activities: the more you work, the more you get. The ability to realize one's potential is correlated with the protection of individual freedoms, which primarily implies liberation from state interference.

These provisions are disclosed and specified in the following indicators: 1) free market economy and private property as a basis for organization of social life (priority of private initiative; requirements to minimize state intervention in the social and economic spheres;

${ }^{16}$ Грамши А. Тюремные тетради: в 3-х ч. Ч. 1. / пер. с итал. Москва: Политиздат, 1991. C. 65. 
maximum limitation of its controlling and regulating functions; interpretation of social functions of state as a violation of citizens' freedoms and shift of responsibility for his own destiny to the level of society); 2) restriction of the welfare state (the need to observe the principle of narrow selectivity in providing social benefits and services in order to minimize public expenditures on this: assistance only to those categories of population who have objective problems with the possibility of realizing their chances (e.g., orphans, disabled, single families, etc.)); 3 ) effective combination of the principles of the free market and the welfare state (substantiation of the possibility of state intervention in the economic life and a broad interpretation of its social functions in order to overcome unemployment and poverty in society, more equitable implementation of the principle of "equality of chances").

Right (conservatives). Main thesis: social inequality is natural. The place of the individual in the hierarchical structure, which is inherent in the organic society, is determined by traditions and natural social order.

It should be noted here that from the economic standpoint conservatives, as well as liberals, are consistent supporters of the free market and private property. However, they consider their importance from a somewhat specific perspective: as institutions that define social discipline, promote stability in society, and help to increase the level of independence and self-realization of the individual.

The views on the role of the state are also specific: in social and economic terms, approaches within different areas of conservatism vary from categorical requirements of the maximum limitation of state intervention in economic life and reduction of social programs to the recognition of the need for state participation in economic processes to ensure a certain standard of living for all citizens, a combination of moderate conservatism and social liberalism (which is typical for Christian democratic parties). At the same time, it should be noted that in the social and political dimension, conservatives are apologists for strong state power (sometimes even authoritarian), since it is this state that provides the organization and order in society, as well as guarantees the observance of legal norms and traditional values.

The ideological priority of tradition and order inherent in conservatives is revealed and specified in the following indicators: 1) tradition and morality as the fundamental basis of society and its effective development (the requirements of the prohibition of such 
individual lifestyles and types of behavior that do not fit into the conventional, generally accepted moral framework (i.e., evaluated as immoral); support and promotion of traditional family unit as a fundamental value; recognition of the special role of religion and religious institutions in public life); 2) ethnocentrism, cultivation of the national way of life (the people as the highest value; proclamation of traditional national values as the basis of social development; formulation and support on this basis of the national idea; calls for patriotism and nationalism); 3) social harmony (the need to ensure and maintain harmony in a socially heterogeneous society as a means of compliance with the natural, i.e., predetermined, social order).

The degree of radicalization of these demands is directly proportional to the degree of denial of the fundamental liberal and democratic principles of organization of social and political life. Above all, it concerns the attitude of the minorities of any and all kinds and methods of combating their ideological opponents, which, in fact, determines the affiliation of such parties to the category of the ultra-right ones.

Second cluster - "new" (post-material). Turning to the identification of the second group of indicators, we should note that they will determine the affiliation of political power, above all, to the new farright parties whose ideological inspiration was the metapolitical intellectual movement of the "New Right".

Contradicting themselves with the value foundations of the "new left", the "new right" brought into the political discourse post-material issues of the right substance. According to the fair comment of S. Flanagan, the "new left" pushed economic issues aside from the political agenda, but at the same time they provoked a whole set of "new right" issues ${ }^{17}$.

The main thesis within this block can be formulated as follows: the formation of a new, liberal social and cultural reality of post-industrial society, which would be based on the principles of emancipation and egalitarianism accompanied by a departure from the tradition and moral values, and also lead to the decline of the natural social order, based on social inequality. All this leads to the destruction of the institution of traditional family, moral and spiritual degradation of a human, crisis of

${ }^{17}$ Inglehart R., Flanagan S. C. Value Change in Industrial Societies. The American Political Science Review. 1987. Vol. 81, Issue 4. P. 1308. 
national and cultural identity, erosion of state sovereignty, weakening of the national state, deep political and economic crises. The solution for this condition is to implement a policy aimed at restoring the social and cultural status quo, returning to the tradition, morality and natural social harmony, which in its totality is embodied in the idea of building a culturally and ethnically homogeneous national state.

This strategy is disclosed and specified in the following provisions: 1) nationalism and anti-immigrant policy (upholding the principle of privileges (based on ethnic origin) in the matters of citizenship and political rights; requests for tougher immigration controls and repatriation of unemployed immigrants); 2) authoritarianism as an institutional embodiment and realization of the idea of a strong government and state. According to Dutch researcher C. Mudde, authoritarianism in this context must be considered, in particular, as a belief in a rigidly organized society with a strong authority that ensures law and $\operatorname{order}^{18}$ (requirements for guaranteeing a high degree of internal security of the state; strengthening the role of the state in matters of ensuring law and order; the possibility of suspending certain rights and freedoms in order to protect the state from subversive activities); 3) national capitalism and "welfare chauvinism" (counteraction to the domination of foreign financial capital; protectionism, support for the national manufacturer, small and mediumsized businesses by providing tax privileges; guaranteeing a high standard of living, access to social goods and services, employment only for citizens belonging to the indigenous nation); 4) isolationism, antiglobalization or Euroscepticism (negative attitude towards multiculturalism; demands for strengthening and preserving national identity and culture through isolationism and strengthening national homogeneity).

Among the additional indicators of "new right" political parties we can distinguish the following: 1) criticism of traditional right parties for ideological apostasy, transition to positions of liberalism, compromises with ideological opponents, as a result of which they became complicit in creating a new social and cultural reality with its departure from the tradition and morality; 2) criticism of the establishment (antiestablishment position) for "anti-national politics" and "corruption".

18 Mudde C. Populist Radical Right Parties in Europe. Cambridge: Cambridge University Press, 2007. P. 22-23. 
In opposition to the ruling elite and parties they, unlike the "old" right-wing radical forces, do not aim to overthrow the existing political system by operating within it. Effective means of nonviolent change of the modern society have been proposed by the "new right" in the context of rethinking the essence of revolution. It is interesting that for these purposes they referred to their ideological opponents - the left. It is a strategy of "right gramscism" developed by one of the intellectual leaders of the "new right" A. de Benoist based on the mentioned concept of A. Gramsci. Its essence lies in the need to overcome leftist discourse, which dominates in the modern Western political culture, by means of developing a right ideology that is competitive in the new social and cultural circumstances, which intellectuals have yet to put into practice ${ }^{19}$.

\section{Centrist political parties.}

Identifying and analysing the parties of the center, in our opinion, implies the need to adhere to the following methodological principles: first, the understanding of the "center" as a zone of ideological and political rapprochement, touch and interaction of moderate left and right political forces. Second, the conceptualization of "moderation" as: a) a departure from ideological fundamentalism (ideological moderation) manifested in doctrinal synthesis in varying proportions of a number of programmatic provisions of left and right political parties. A striking example of such ideological convergence can be the concepts of liberal socialism (provoking the movement of left parties to the right, respectively, towards the center) and socialist liberalism (causing the displacement of right parties to the left, i.e., also to the center); b) rejection of the violent means of achieving programmatic goals and recognition of the established rules of political play (instrumental moderation). This manifests in respect for the fundamental liberal-democratic principles in general and the methods of political struggle, in particular, the willingness to engage in broad dialogue and to reach a compromise with one's political and ideological opponents.

Third, the conceptualization of ideological moderation as a partially synthesized doctrinal community with left and right is revealed and

19 Тэвдой-Бурмули А. Правый радикализм в Европе. Современная Европа. 2005. № 4. C. 91-92. 
specified in the following provisions: 1) the need for partial state control and regulation of the market, mixed ownership (the possibility of effective coexistence of private and state property, selective nationalization, social market economy, demands of full implementation of the principles of the welfare state, observance of the principle of wide selectivity in providing social goods and services) - "left center"; 2) the need to effectively combine the principles of the free market and the welfare state (the possibility of state intervention in economic life and a broader interpretation of its social functions in order to overcome unemployment and poverty in society, more equitable implementation of the principle of "equality of chances") - "right center" (liberals); 3) the need for state participation in economic processes to ensure a certain standard of living for all citizens, a combination of the principles of moderate conservatism and social liberalism - the "right center" (Christian democratic parties).

It should be noted that the main lines of contact, both between the centrist parties themselves, and between them and the left and right parties, lie in the "traditional" (material) dimension. That is, the ideological communities here are formed around the issues of property, the role of the state in economic life, the principles of economic distribution and the provision of social goods and services. Problems that are not related to this area (for example, "traditional morality", "freedom", "decentralization") are subject to ideological compromises to a lesser extent ${ }^{20}$.

This leads us to believe that the formation of center parties (center-left and center-right) is the result of the conclusion of a broad ideological and political compromise in modern liberal society regarding the basic foundations of its development and, as a consequence, the convergence of exclusively between the traditional (the "old") left parties (mainly in terms of social and economic issues), for which, as noted above, they are criticized, respectively, by the "new left" and "new right". Therefore, we cannot speak of ideological convergence in the "new" (social and cultural) dimension, and, consequently, of the existence of a certain "new center" party, which would be located between the "new left" and "new right".

${ }^{20}$ Keman H. The Search for the Center: Pivot Parties in West European Party Systems. West European Politics. 1994. Vol. 17, Issue 4. P. 138. 
Thus, the reference to the methodological approaches of N. Bobbio and D. Jahn enables us not only to distinguish the main ideological oppositions that underlie the "left-right" party-ideological delineation, but also to clarify the specifics of the definition of left and right political forces, given the particular social and political development of a particular country or region (i.e., to establish additional criteria for identifying left and right in that country or region). Therefore, for the fullfledged scientific application of the "left-right" party-ideological delineation in the context of structuring the political field of the postSoviet countries, including Ukraine, we need to determine the specificity of the aforementioned delimitation in the political systems of the postcommunist states of Central and Eastern Europe.

\section{Specificity of "Left-Right" Party-Ideological Differentiation in the Political Field of Post-Communist States: Peculiarities of the Analysis}

Our initial methodological position is the position of the theory of pluralization about the coexistence in the political landscape of the modern states of traditional (material) and new (post-material) definitions of left and right, which do not displace each other from a political discourse, but only become more or less significant in the context of a certain social, political and economic situation ${ }^{21}$. This approach makes it possible to rethink the traditional view of "left-right" delineation of political sphere in a one-dimensional linear division: the need to consider material and post-material issues in determining the essential characteristics of left and right turns it into two-dimensional. That is, it acquires an orthogonal structure, within which one axis reflects the traditional distinction based on material (economic) issues and the other new, based on post-material (social and cultural) problems. Within the framework of such a two-dimensional structure, there is a "left-right" positioning of political forces: in some conditions, focusing on economic issues, in others - on social and cultural.

The use of a two-dimensional structure of "left-right" partyideological delineation is an indispensable methodological tool in the context of identifying the peculiarities of the appropriate division of

${ }^{21}$ Kitschelt H., Hellemans S. The Left-Right Semantics and the New Politics Cleavage. Comparative Political Studies. 1990. Vol. 23, Issue 2. P. 215-216. 
political forces in the post-communist states of Central and Eastern Europe. Only in this way the whole palette of cognitive possibilities is revealed, firstly, to capture the differences that exist between the positioning of parties in the consolidated democracies of the West and in the post-communist states of the region, which determine different options of the combination of material and post-material issues; secondly, to effectively overcome this conceptual difficulty in identifying left and right in the political sphere of Central and Eastern Europe.

Therefore, according to the theoretical approach of German researcher $\mathrm{H}$. Kitschelt, in modern democracies the main political distinctions that determine inter-party competition revolve around three main questions: Who is the player? What are the rules of collective choice? How should players be endowed with resources? In the political and practical dimension, these issues are specified in the definition, first, by the criteria of citizenship; second, by collective decision-making procedures; third, by the criteria for allocating resources and opportunities among citizens ${ }^{22}$.

Based on this methodological approach, H. Kitschelt substantiated the position that the fundamental basis for differences in the structure of party competition (and, respectively, and in the positioning of parties within the two-dimensional "left-right" division) of developed democracies and post-communist countries embarking on the path of democratization, are their different economic status quo or, in other words, different starting points for resource allocation criteria. The positioning of parties in this material dimension determines the specificity of their answers to the first two of the mentioned questions, which are intangible.

Thus, the structure of party competition and the peculiarities of material and post-material issues are compounded by the fundamental conflict between defenders and opponents of existing property rights and economic distribution models: defenders of the economic status quo, unwilling to threaten it, oppose the processes of democratization and the process of liberalization of citizenship, because, according to $\mathrm{H}$. Kitschelt, in the future, these processes lead to unpredictable changes

${ }^{22}$ Kitschelt H. The Formation of Party Systems in East Central Europe. Politics and Society. 1992. Vol. 20, Issue 1. P. 11-13. 
in the division of resources. Therefore, the defenders of the preservation of existing economic relations will always adhere to traditionalist, nationalist and authoritarian positions, seeking to prevent the political rights of new social groups (including them in the political process) from being granted political rights and limiting the empowerment of citizens in the political decision-making process.

Thus, according to H. Kitschelt's approach, in the West, where the status quo is a market economy, its defenders are "new right" who are at the same time nationalists, traditionalists (paternalists) and supporters of authoritarian principles of governing and the political decision-making. Consistent opponents of the current economic system here are the "new left", who supplement their anti-market position with libertarian demands for the liberalization and democratization of social and political life, advocating, in particular, for the expansion of the sphere of political participation of citizens and the decentralization of political decisionmaking procedures.

Instead, in the post-communist states, where the economic status quo was diametrically opposite at the beginning of the processes of their social, political and economic transformation - the non-market mode of resource allocation (planned economy), the situation with parties regarding material and post-material issues was fundamentally different. Defenders of the status quo here are mostly left-wing political parties that oppose liberal-democratic reforms, appealing to those social groups that have suffered (lost) most as a result of transit to a market economy and a democratic political system. Hence, the aforementioned political forces occupy traditionalist, nationalist and authoritarian positions.

Supporters of the market economy, and therefore the opponents of maintaining the status quo in these countries are the right political parties. They actively advocate for deep liberal-democratic reforms in order to broaden the scope of political participation of citizens and to eliminate the system of economic distribution based on non-market mechanisms. Moreover, these political forces represent the so-called "winners" of transit. However, the exceptions here are the far-right parties. They belonged to the anti-communist opposition, but because of their ideological convictions, they supported traditionalist, nationalist and authoritarian values. Therefore, according to $\mathrm{H}$. Kitschelt, these parties are more likely to resist the liberalization and democratization of political 
life and hinder the transition to a market economy than act as catalysts for these transformations ${ }^{23}$.

A comprehensive approach to the explaining the peculiarities of the party competition structure of the post-communist states of Central and Eastern Europe and identifying in this context the specifics of the left and right parties combining issues of material and post-material nature were suggested by American researcher $M$. Tavits and Polish scientist $\mathrm{N}$. Letki. Their initial methodological setting is a provision according to which the choice of a particular policy by all parties in the region is determined by the following factors: the legacy of the previous regime, and the dual nature of transit - towards democracy and a market economy.

We mean that on the one hand, large-scale economic reforms, accompanied by widespread unemployment, high inflation, low economic growth and, as a consequence, reduced fiscal revenues, have put the need for tight budgetary measures on the agenda, primarily by reducing government spending on social policy. On the other hand, the transformation of a planned economy with a broad social security system into a liberal market economy has led to the formation of large groups of citizens who have lost their jobs, stable income and social support from the state. Thus, they clearly associate the significant decrease in their standard of living and the increase of social and economic inequality in society with the implementation of economic reforms aimed at the rapid transition from the universal welfare state that existed under the previous regime to the free market. Against this background, these groups form a significant public demand for left-wing economic policies related to the rebuilding of the broader social security system in particular and of "socialist justice" as a whole, which existed under the previous regime.

In these circumstances, all parties have to choose between two diametrically opposite types of policy (right and left), the main parameters of which are set by the following strategic alternatives: either the realization of effective economic factors for the implementation of a business with an economic economy (and it uses its political policy), or the satisfaction of the most important economic problems concerning

${ }^{23}$ Kitschelt H. The Formation of Party Systems in East Central Europe. Politics and Society. 1992. Vol. 20, Issue 1. P. 15-41. 
public records for public servants in support ${ }^{24}$. A particular attention should be paid here to the fact that the choice of one or the other party by one of the two alternatives mentioned does not always coincide with the ideological principles fixed in its program.

Thus, in particular, some of the left-wing parties prefer the right economic policy, even though, in the face of social and economic difficulties and the increasing number of "transit failures", the leftwing policy alone is more favourable from an electoral point of view. However, this applies only to those left who seek to effectively integrate into the new political and economic reality of the postcommunist states by a complete break with the communist past. After the fall of authoritarian regimes in Central and Eastern Europe, the left was said to be unpopular in society and not considered by other parties as possible partners, as they were perceived as successors of previously ruling communist parties and carriers of discredited authoritarian communist ideas.

In these circumstances the most successful strategy for adapting to the new reality for those left-wing parties that declared their complete break with communist ideology and the transition to the positions of social democracy, was the rejection of nostalgia for the socialist past, as well as unpardonable appeals, could be interpreted as the desire of these parties to return to the old regime. Therefore, in order to get rid of the rogue status in the political system, to participate effectively in electoral campaigns and gain power, these parties had not only to fix their commitment to democracy and the free market, but also to pursue the right economic policy, including as political forces in charge. Moreover, such a choice by the left-wing parties of the right economic policy does not lead to the loss of their traditional supporters. This is due in particular to the fact that they have a clear socialist image: left-wing voters perceive right-liberal economic reforms carried out by left parties as really necessary, justified and thoroughly considered - why else do parties with a socialist ideology perform a suicidal policy from the point of view of the electorate? In addition, the radical decommunization that has taken

${ }^{24}$ Tavits M., Letki N. When Left is Right: Party Ideology and Policy in PostCommunist Europe. American Political Science Review. 2009. Vol. 103, Issue 4. P. 555556; Tavits M., Letki N. From Values to Interests? The Evolution of Party Competition in New Democracies. The Journal of Politics. 2014. Vol. 76, Issue 1. P. 248-249. 
place in some countries in the region has strongly tied voters with a communist past to the left, especially to former communist parties ${ }^{25}$.

Right-wing parties, on the other hand, do not have as much loyal and stable electorate as left-wing parties (among the main reasons, in particular, greater fragmentation in the Central and Eastern European countries of the right side of the party spectrum than the left, as well as the lack of right-wing and strong party organizations, that leftist have), forced to prevent the loss of votes of those who are frustrated with the reforms, to turn and implement a leftist economic policy: to support under the slogans of protecting the people from the negative effects of economic have formed the need for state intervention in the economy and have increased spending on social programs ${ }^{26}$.

However, these policies of right-wing or center-right parties can cause voter distrust and therefore might not bring them the required electoral result. In this case, these parties are trying to implement another strategy: to shift voters' attention to economic and cultural issues, such as nationalism, traditional morality, anti-multiculturalism, decommunization, minority rights (their interpretation as a threat to majority rights).

In other words, right-wing parties here seek to downplay the importance of economic problems and shift the mainstream of party competition with the left into the post-material dimension, in which they intend to increase their electoral support, intensely appealing to these issues. Also, this strategy allows the right-wing parties, which, economically speaking, prefer the "left" policy, to maintain their own general ideological identity. However, the mentioned strategy will be successful only if there are social divisions on the ethnic and/or religious basis in society that can politicize the right parties $^{27}$.

All this has led researchers to deduce and substantiate the following correlations: first, the increase in social and economic inequality is more likely to reduce the importance of post-material dimension of party competition (reflected in the convergence of party positions in this

${ }^{25}$ Tavits M., Letki N. When Left is Right: Party Ideology and Policy in PostCommunist Europe. American Political Science Review. 2009. Vol. 103, Issue 4. P. 555-558.

${ }^{26}$ Ibid. P. 567.

${ }^{27}$ Tavits M., Letki N. From Values to Interests? The Evolution of Party Competition in New Democracies. The Journal of Politics. 2014. Vol. 76, Issue 1. P. 247-249. 
dimension) in ethnically homogeneous societies rather than in ethnically homogeneous ones; second, increasing social and economic inequality is more likely to reduce the importance of the post-material dimension of party competition in secular than in religious societies; third, the presence in the society with large social and economic inequalities of both ethnic and religious social divisions creates especially favourable opportunities for parties to intensify the post-material dimension of party competition; fourth, in societies with large social and economic inequalities, where there is a strong demand for left-wing economic policy, the left-wing parties will emphasize on the economic dimension of party competition and the right-wing parties otherwise will emphasize on social and cultural dimension ${ }^{28}$.

Therefore, based on the theoretical approaches analysed, we can conclude that the following methodological parameters in the study and determination of the specifics of the "left-right" party-ideological differentiation in the post-communist states of Central and Eastern Europe are as follows:

- peculiarities of positioning the left-wing parties within the framework of the two-dimensional structure of the "left-right" partyideological differentiation, and therefore the specificity of the combination of material and post-material issues is conditioned by their chosen strategies of adaptation to the new social, political and economic conditions resulting from the double transit from the communist authoritarian regime towards democracy and the free market. Therefore, if a political force has chosen the path of ideological and organizational development in the format of the Social Democratic Party, whose leaders position themselves as technocrats and pragmatists, for whom the effective solution of current political and economic problems, rather than ideological issues, is of paramount importance, it will stand on moderately pro-market positions in a material dimension (on the one hand, criticism of the neoliberal model of capitalism, which allows the party to retain its socialist image, and on the other, a commitment to the market mechanisms that must be viable within a mixed economy), and within the post-material - parties will defend the need for liberalization and democratization of political life. In this way, the party is focused both

${ }^{28}$ Tavits M., Letki N. From Values to Interests? The Evolution of Party Competition in New Democracies. The Journal of Politics. 2014. Vol. 76, Issue 1. P. 253-256. 
on maintaining its traditional voters, a large part of them are "transit losers", and in attracting new voter groups, including "transit winners".

If a party positions itself as a political force that is consistently committed to socialist ideals, then in a material dimension it will stand in clear anti-market positions, and in the post-material - it will appeal to traditionalist, nationalist and authoritarian values. In this way, the party, actively using the nostalgia for the "socialist past", aims to obtain maximum support from the "transit losers", who it promises to protect against "predatory" neoliberalism and to restore the "traditional socialist order" in society.

It should be noted that a consistent anti-market, anti-capitalist position is also upheld by the "new left" parties. However, being committed to socialist ideals, they at the same time categorically break with the model of socialism that the Soviet Union sought in the past to lead to the enslavement of man and the establishment of an authoritarianbureaucratic system. Therefore, as far as they can distance themselves from the "socialist past" and uphold the libertarian principles in the postmaterial dimension, they focus primarily on attracting new social groups - post-materialists, as well as a certain part of the "transit losers";

- peculiarities of positioning the right-wing parties within the framework of the two-dimensional structure of the «left-right» partyideological differentiation, and therefore the specificity of the combination of material and post-material issues is conditioned by the degree of effectiveness of those political, social and economic transformations that takes place in post-communist societies. The point is that right-wing, being the main heirs to the anti-communist opposition that existed under the previous regime, were the main initiators of the liberal and democratic transformations in the social, political and economic spheres at the beginning of the transit. However, the further course of these reforms identified different options for combining the right economic and social and cultural issues. Therefore, the right (liberals) in the material dimension are consistent supporters of the free market, in the post-material - libertarian values. Increasing social and economic inequality in society causes them to soften their liberal economic policies, which is manifested in their shift to the left-wing and the transition to positions of left-wing (social) liberalism. By advocating for a socially-oriented market economy and increasing government spending on social programs, they seek to minimize the negative effects 
of economic reform. In this way, they represent the interests of "transit winners" in the first place and focus on attracting some of the "transit losers".

Rights (conservatives) in the material dimension are supporters of the free market, and in the post-material are supporters of the traditionalists, nationalists and authoritarian values. In the face of increasing of social and economic inequality in society, they focus precisely on social and cultural issues, seeking to shift voters' attention from economic problems and maintain their right-wing identity within the framework of a forced appeal to left-wing economic policy. This is especially characterising the extreme right-wing parties, which, in material terms, oppose the neoliberal model of market relations and argue for the need to develop a national-oriented market economy (national capitalism), from the standpoint of protectionism and of such a model of economic redistribution, which will provide benefits to the indigenous peoples (economic nationalism). In this context, they appeal to leftist ideas about the need for government intervention in economic policy and for increasing the cost of social programs. In the post-material dimension, they reject the denial of libertarian values that violates the "traditional order", speaking from the standpoint of nationalism, anti-multiculturalism and traditional (religious) morality. In this way, the aforementioned political forces are oriented towards attracting the voices of both nationalist and / or religious "transit losers" of transit and those "winners" of transit who have clear "new right" ideological attitudes.

\section{CONCLUSIONS}

Thus, the research shows: firstly, how by applying a deductive (a priori) approach, to find out that the fundamental ideological opposition, which determines the essence of the "left-right" partyideological delineation, is to oppose the principles of equality and social hierarchy (inequality).

Secondly, to find out that the differentiation has a dynamic and varied character. That is, it must be taken into account that the meaningful content of the concepts of "left" and "right" is not constant, but varies depending on the characteristics of a particular stage of social evolution and social and political specificity of a particular region or individual state. Therefore, it is necessary to determine the basic and additional characteristics of the left and right. The main ones are stable 
and valid at all times and contexts, allowing for a clear "left-right" distinction of political forces, while additional ones are subject to change depending on time and context, which helps to capture the features of the "left-right" dichotomy in different periods and its national specificity.

Thirdly, to determine that at the present stage of social and political evolution, in the conditions of transition from advanced industrial states to the post-industrial stage of development, there is a change in the traditional concept of "left-right" delimitation in the format of onedimensional linear division. We are talking about its complication. That is, based on the principles of the theory of pluralism, we substantiated the need to consider in determining the essential features of left and right as traditional (material) and new (post-material) issues. In these circumstances, this separation acquires a two-dimensional, orthogonal structure, within which one axis reflects the traditional distinction based on material (economic) issues and the other - new one based on postmaterial (social and cultural) problems.

Fourthly, to find out the specifics of the "left-right" party-ideological division in the political systems of the post-communist countries of Central and Eastern Europe. It is caused by the peculiarities of the double transit of the states of the mentioned region - from authoritarianism to democracy; from planned to market economy. This determines the differences that are based on diametrically opposite variants of the combination of material and post-material issues by parties in the structures of party competition of post-state states and countries with a consolidated democratic regime.

Fifthly, drawing on the aforementioned methodological frameworks, to create indicators lists that can be used to identify the affiliation of a particular political force to the left (or "new left"), right (or "new right") or centrist (center-left or center-right) parties.

\section{SUMMARY}

The article, based on a deductive (a priori) approach, found that the fundamental ideological opposition, which determines the essence of the "left-right" distinction, is the juxtaposition of the principles of equality and social hierarchy (inequality). This demarcation has been found to have a dynamic, variable nature. Indicators have been determined that will allow the identification of a particular political force for the left (or "new left"), right (or "new right") or centrist (center-left / center-right) 
parties. The specificity of the "left-right" party-ideological delineation, which has developed in the political space of the post-communist states of Central and Eastern Europe, has been determined. It is proved that the peculiarities of positioning of the left parties within the framework of the two-dimensional structure of the "left-right" party-ideological division, and, consequently, the peculiarity of the combination of material and post-material issues are due to their chosen strategies of adapting to the new political and economic conditions that resulted from the double transit of the states of the mentioned region - from authoritarianism to democracy; from planned to market economy. It is substantiated that the peculiarities of positioning the right parties within the framework of the two-dimensional structure of the "left-right" party-ideological division, and therefore the specificity of the combination of material and postmaterial issues, are conditioned by the degree of effectiveness of those political and social and economic transformations that occur in postcommunist societies.

\section{REFERENCES}

1. Грамши А. Тюремные тетради: в 3-х ч. Ч. 1. / пер. с итал. Москва: Политиздат, 1991. 560 с.

2. Инглхарт Р. Постмодерн: меняющиеся ценности и изменяющиеся общества. Полис. 1997. № 4. С. 6-32.

3. Маркузе Г. Одномерный человек / пер. с англ. А. Юдина. Москва: REFL-book, 1994. XXII, 368 с.

4. Тэвдой-Бурмули А. Правый радикализм в Европе. Современная Европа. 2005. № 4. С. 86-98.

5. Bobbio N. Left and Right: The Significance of a Political Distinction / translated and introduced by A. Cameron. Chicago: The University of Chicago Press, 1997. XXII, $124 \mathrm{p}$.

6. De Vries C. E., Hakhverdian A., Lancee B. The Dynamics of Voters' Left/Right Identification: The Role of Economic and Cultural Attitudes. Political Science Research and Methods. 2013. Vol. 1, Issue 2. P. 223-238.

7. Downs A. An Economic Theory of Political Action in a Democracy. The Journal of Political Economy. 1957. Vol. 65, Issue 2. P. 135-150. 
8. Huber J., Inglehart R. Expert Interpretations of Party Space and Party Locations in 42 Societies. Party Politics. 1995. Vol. 1, Issue 1. P. 73-111.

9. Inglehart R., Flanagan S. C. Value Change in Industrial Societies. The American Political Science Review. 1987. Vol. 81, Issue 4. P. 1289-1319.

10. Inglehart R., Klingemann H.-D. Party Identification, Ideological Preference and the Left-Right Dimension among Western Mass Publics. Party Identification and Beyond: Representations of Voting and Party Competition / I. Budge, I. Crewe, D. J. Farlie (eds.). Colchester: ECPR Press, 2010. P. 243-274.

11. Jahn D. Conceptualizing Left and Right in Comparative Politics: Towards a Deductive Approach. Party Politics. 2011. Vol. 17, Issue 6. P. 745-765.

12. Jahn D. What is Left and Right in Comparative Politics? A Response to Simon Franzmann. Party Politics. 2014. Vol. 20, Issue 2. P. 297-301.

13. Keman H. The Search for the Center: Pivot Parties in West European Party Systems. West European Politics. 1994. Vol. 17, Issue 4. P. 124-148.

14. Kitschelt H. The Formation of Party Systems in East Central Europe. Politics and Society. 1992. Vol. 20, Issue 1. P. 7-50.

15. Kitschelt H., Hellemans S. The Left-Right Semantics and the New Politics Cleavage. Comparative Political Studies. 1990. Vol. 23, Issue 2. P. 210-238.

16. Knutsen O. Value Orientations, Political Conflicts and Left-Right Identification: A Comparative Study. European Journal of Political Research. 1995. Vol. 28, Issue 1. P.63-93.

17. Mudde C. Populist Radical Right Parties in Europe. Cambridge: Cambridge University Press, 2007. 385 p.

18. Rosas J. C., Ferreira A. R. Left and Right: Critical Junctures. Left and Right: The Great Dichotomy Revisited / J. C. Rosas, A. R. Ferreira (eds.). Newcastle upon Tyne: Cambridge Scholars Publishing, 2013. P. 2-20.

19. Tavits M., Letki N. From Values to Interests? The Evolution of Party Competition in New Democracies. The Journal of Politics. 2014. Vol. 76, Issue 1. P. 246-258. 
20. Tavits M., Letki N. When Left is Right: Party Ideology and Policy in Post-Communist Europe. American Political Science Review. 2009. Vol. 103, Issue 4. P.555-569.

21. Weber W. Behind Left and Right. The Meaning of Left-Right Orientation in Europe. URL: http://www.tdx.cat/bitstream/handle/ 10803/107624/tww.pdf?sequence=1. 153 p. （дата звернення: 21.09.2019).

\section{Information about the author: Shypunov H. V.}

Doctor of Political Sciences, Associate Professor, Department of Theory and History of Political Science, Ivan Franko Lviv National University 1, Universytetska str., Lviv, 79000, Ukraine

Prokop M.

$\mathrm{PhD}$ (Candidate of Political Sciences), Adjunct, Institute of International Relations and Public Policies, Faculty of Law and Social Sciences, Jan Kochanowski University in Kielce, Kielce, Poland 